PII: S0045-6535(99)00035-1

\title{
Development and Implementation of Source Water Quality Standards in Taiwan, ROC
}

\author{
E.E. Chang ${ }^{1 *}$, P.C. Chiang ${ }^{2}$, S.H. Chao ${ }^{1}$ and C.L. Chuang ${ }^{2}$
}

\begin{abstract}
1. Department of Biochemistry, Taipei Medical College, Taipei, Taiwan, ROC.
2: Graduate Institute of Environmental Engineering, National Taiwan University, Taipei, Taiwan, ROC.

(Received in Germany 9 November 1998; accepted 15 January 1999)
\end{abstract}

\begin{abstract}
The Environmental Protection Administration of ROC (ROCEPA) is seeking cost-effective alternatives to meet the drinking water standards. The alternatives include promulgating more stringent regulations to protect the drinking water sources and/or constructing advanced water treatment plants to comply with the requirements of drinking water standards. The objectives of this research were first to develop a rationale for selecting representative water quality parameters and then determining their respective contaminant level (or regulated value) for the source water quality standards in Taiwan, ROC. The implementation plans are proposed to achieve the goal of safe drinking water in Taiwan. O1999 Elsevier Science Ltd. All rights reserved
\end{abstract}

Key Words : Source water quality standards, implementation regulations, composite correction program (CCP), comprehensive performance evaluation (CPE).

\section{INTRODUCTION}

The quality of the source water is deteriorating rapidly due to water pollution and human activities throughout the world. Discharge of domestic and industrial wastewaters have contributed significant pollutants to the source water. Meanwhile, the water treatment plants are not upgraded in a timely fashion for adequately treating the source water in compliance with the drinking water standards. In June of 1975, the Council of European Communities (EC) adopted a Council Directive for the Member States concerning the required quality of surface water intended for the abstraction of drinking water [1]. The EC Directive divided raw water quality criteria into three classes according to the respective water treatment methods. Class 1 water treatment involves simple purification processes including filtration and disinfection. Class 2 water treatment includes coagulation, flocculation, sedimentation, filtration and disinfection. Class 3 , the most 
extensive method, includes Class 2 processes and the activated carbon process. For each class of source water criteria, there are two sets of limit values. One set is a mandatory limit and the other is used for guidance.

In April of 1970, the Water Quality Committee of the Japanese Living Environment Council published water quality standards for water resources area to protect the source water quality as well as public health. Similar to the EC Directive, Japanese source water standards were divided into three classes according to the type of water purification process [2]. In 1971, the United States Public Water Supplies Panel at the request of the USEPA proposed water quality criteria for source water [3]. The source water quality criteria of the USEPA were established based on water treatment processes, which are similar to Class 2 of the EC Directive as stated previously. The water treatment processes include: (1) coagulation (less than about 50 $\mathrm{mg} / \mathrm{l}$ alum, ferrous sulfate, or copperas with alkali or acid addition as necessary but without coagulant aids or activated carbon) (2) sedimentation (detention time 6 hours or less); (3) rapid sand infiltration (loading rate three gallons per square foot per minute or more); and (4) disinfection with chlorine.

The surface water quality standards of the ROC (Republic of China), in accordance with the water quality criteria issued in the water pollution control act [4], were divided into three classes based on water treatment processes. For Class I, the treatment plant only needs to provide disinfection unit process. The water utility has to provide the coagulation, sedimentation, filtration, and disinfection processes to meet the Class II requirement. In Class III, the advanced treatment are necessary to install the ozonation, activated carbon, ion exchanger, and/or reverse osmosis (membrane) processes. The need for standards to screen source water for the public supplies use is well recognized. However, source water standards in cooperation with drinking water standards to safeguard the public supply is still under dispute. The approach of the ROCEPA is to set up a rational standard of source water quality. When the source water quality does not comply with the standards, the ROCEPA would encourage the water industry to refine the existing facilities or install advanced facilities to meet the requirements.

In 1992, the ROCEPA reported the Enforcement Rules of Statute Governing Drinking Water and Source Water Standards for Public Supplies [5]. Thereafter in 1994, the EPA proposed setting source water quality standards and monitoring frequency for selected contaminants. The objectives of this research were to develop a rationale for selecting representative water quality parameters and determining their respective contaminant level (or regulated value) for the source water quality standards in Taiwan [6]. The implementation plan tasks are proposed to achieve the goal of safe drinking water in Taiwan.

\section{RATIONALES FOR DEVELOPING SOURCE WATER QUALITY STANDARDS}

In selecting water quality parameters for source water criteria, each parameter should be a representative indicator for water pollution and a long term toxic substance which should be enforceable 
and adopted by other countries. In determining the regulated values for the above parameters, the following factors must be considered: (1) regulated values of other countries; (2) the existing and future drinking water standards; (3) background data of the current source water quality; (4) the introduced water treatment processes in Taiwan and (5) administrative and analytical problems encountered during execution of the source water criteria. Table 1 presents the source water quality criteria for the developed nations and would provide the general guidelines for developing the source water quality standards in Taiwan, ROC. At this juncture, source water quality standards are established through a procedure of evaluation by experts and scholars in a technical committee as shown in Figure 1.

Table 1. Comparison of the source water quality criteria in the developed nations

\begin{tabular}{|c|c|c|c|c|c|c|}
\hline Parameter Units & USEPA & $\begin{array}{l}\text { Alberta, } \\
\text { Canada }\end{array}$ & $\mathrm{EC}(\mathrm{A} 1)$ & Japan & Australia & $\begin{array}{c}\text { Germany } \\
\text { (Rhine-River) }\end{array}$ \\
\hline \multicolumn{7}{|l|}{ I. Microorganisms } \\
\hline $\begin{array}{l}\text { Total coliform } \\
\text { (CFU/100mL) }\end{array}$ & 20000 & 5000 & - & 5000 & $<10$ & - \\
\hline $\begin{array}{l}\text { Fecal coliform } \\
\text { (CFU/100 mL) }\end{array}$ & 2000 & 1000 & - & - & ND & - \\
\hline \multicolumn{7}{|l|}{ II. Physical parameters } \\
\hline Color (TCU) & $<75$ & $\leqq 30$ & 20 & 10 & 15 & 0.5 \\
\hline $\mathrm{PH}$ & $5.0-9.0$ & $6.5-8.5$ & - & - & $6.5-8.5$ & $6.5-8.5$ \\
\hline \multicolumn{7}{|l|}{ III. Inorganics (mg/L) } \\
\hline As & 0.1 & 0.01 & 0.05 & 0.1 & 0.05 & 0.005 \\
\hline $\mathrm{Ba}$ & 1 & 1.0 & 0.05 & & 1.0 & 0.7 \\
\hline $\mathrm{Cr}$ & 0.05 & 0.05 & 0.05 & 0.05 & 0.05 & 0.025 \\
\hline $\mathrm{Cd}$ & 0.01 & 0.01 & 0.005 & 0.01 & 0.005 & 0.003 \\
\hline $\mathrm{Hg}$ & 0.002 & 0.0001 & 0.001 & ND & 0.001 & 0.0005 \\
\hline $\mathrm{Pb}$ & 0.05 & 0.05 & 0.05 & 0.01 & 0.05 & 0.005 \\
\hline $\mathrm{Se}$ & 0.01 & 0.01 & 0.01 & & 0.01 & 0.005 \\
\hline $\mathrm{Ag}$ & 0.001 & 0.05 & - & & 0.05 & \\
\hline $\mathrm{Cu}$ & 1 & 0.02 & 0.05 & 1.0 & 1.0 & \\
\hline $\mathrm{Fe}$ & 0.3 & 0.3 & 0.3 & 0.3 & 0.3 & \\
\hline $\mathrm{Mn}$ & 0.05 & 0.05 & - & 0.05 & 0.1 & \\
\hline $\mathrm{Zn}$ & 5 & 0.05 & 3 & 1.0 & 0.05 & \\
\hline $\mathrm{NH}_{3}-\mathrm{N}$ & 0.5 & $1.0(\mathrm{TKN})$ & - & 0.5 & 0.01 & 0.3 \\
\hline $\mathrm{Cl}^{-}$ & 250 & 1.5 & - & 200 & 400 & 100 \\
\hline $\mathrm{CN}^{-}$ & 0.2 & 0.015 & 0.05 & ND & 0.1 & 0.025 \\
\hline $\mathrm{NO}_{3}^{\circ}$ & 10 & - & 50 & 9 & 10 & \\
\hline $\mathrm{SO}_{4}^{2-}$ & 25 & $0.05\left(\mathrm{~S}^{2-}\right)$ & 250 & & 400 & 100 \\
\hline \multicolumn{7}{|l|}{ IV. Organics (mg/L) } \\
\hline Surfactants (MBAS) & 0.5 & - & - & 0.5 & - & - \\
\hline Phenol & - & 0.005 & 0.001 & 0.005 & - & - \\
\hline Total pesticides & - & - & 0.0002 & - & - & 0.05 \\
\hline $\mathrm{COD}\left(\mathrm{KMnO}_{4}\right)$ & - & - & - & 3 & - & - \\
\hline PCB & - & - & - & - & 0.0001 & - \\
\hline PAHs & - & - & 0.0002 & - & - & 0.0001 \\
\hline
\end{tabular}




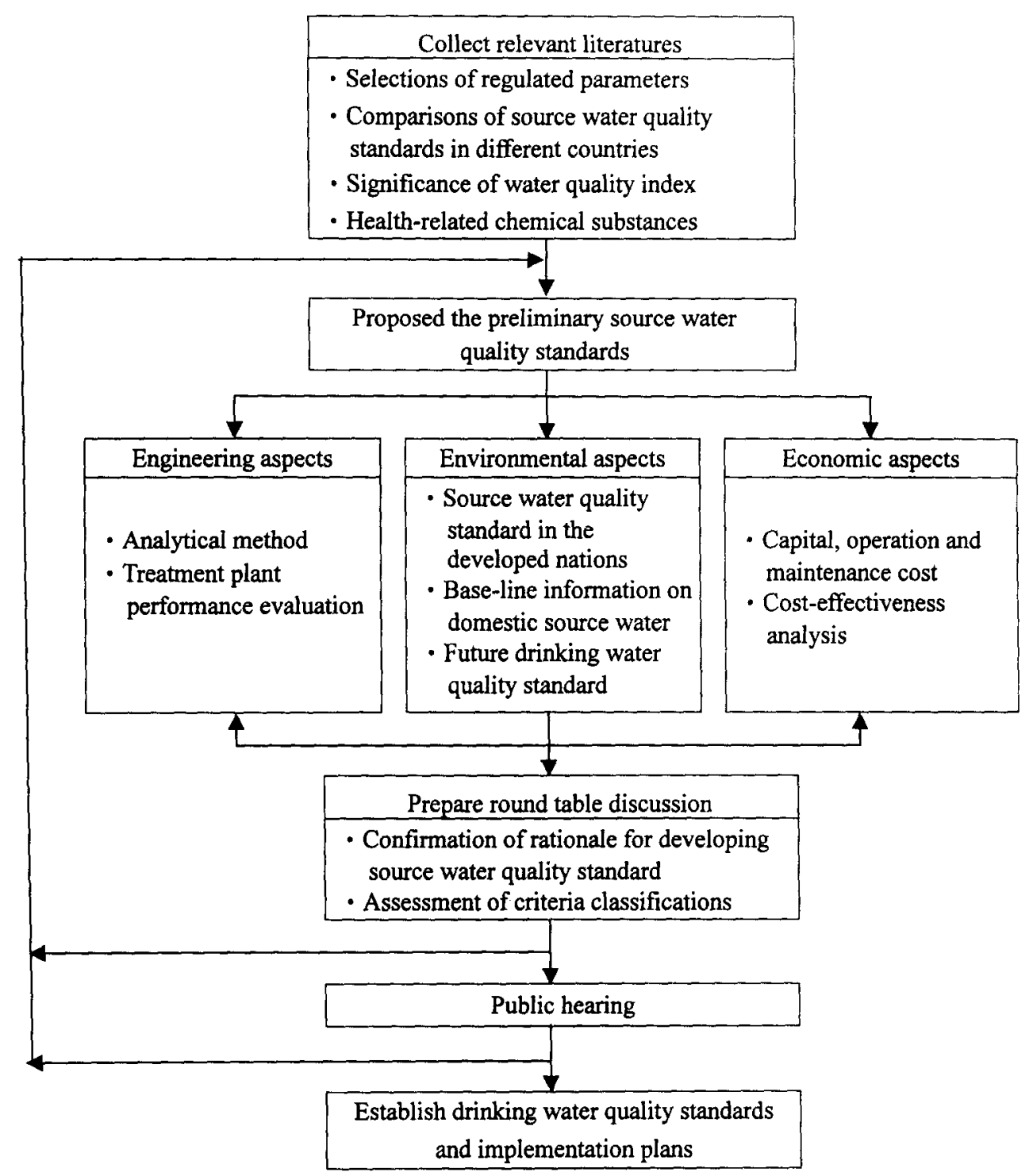

Figure 1. Procedures to develop and implement the source water quality standard in Taiwan

To simplify the administrative procedure, it is recommended that the implementation of source water standard be separated into two stages. In the first stage, source water standard will be established and enforced for a water treatment plant equipped with conventional treatment methods including the coagulation, flocculation, sedimentation and disinfection processes. Source water quality standards of ROCEPA established in the first stage are similar to those of the USEPA except that only representative items with less stringent limits. After a satisfactory execution of Stage I, the criteria classification suggested by Japan and EC can be used as references in the second stage. 
In surface water quality, TOC, COD, total coliforms and ammonia nitrogen are potential contaminants contributed by microbial communities and human activities. As, $\mathrm{Cr}, \mathrm{Cd}, \mathrm{Hg}$, and $\mathrm{Pb}$ are toxic substances found to cause adverse effects on human heath. Since these elements are health related substances, the current drinking water quality standards should be primarily concerned in setting a reasonable limit on them $[7,8]$. Other factors, including the classification of national water, source water criteria adopted by other countries and the background data of water quality were also considered to develop the source water quality standards.

\section{TOC. COD and Total Coliforms}

Some organic compounds, such as lignin, tannin, humic substances, and various aromatic compounds commonly found in water are precursors of DBPs (disinfection by products) and can be measured by the TOC determination [9-11]. Total coliforms, and TOC (or COD) are potential contaminants contributed by microbial communities and human activities, respectively. The criteria or regulated standards for these surrogated parameters, i.e., TOC, COD and total coliforms have to be comprehensively evaluated based on the nationally and internationally available information. For instance, the USEPA Disinfectant/Disinfection by-product rules require the use of enhanced coagulation by utilities to treat surface water containing TOC concentrations above a certain level $[12,13]$. As a result, it might be proposed to adopt $4.0 \mathrm{mg} / \mathrm{L} \mathrm{TOC}$ as a source water criteria at the present time and to implement more stringent value $(2.0 \mathrm{mg} / \mathrm{L} \mathrm{TOC})$ in the next phase.

This hypothesis could be confirmed by our previous research work [14] presented in Table 2 which depicts the relationship between TOC and THM formation at fixed chlorine dose $(2.0 \mathrm{mg} / \mathrm{L})$. Results indicate that, at a contact time of 40 minutes, when $\mathrm{TOC}=4 \mathrm{mg} / \mathrm{L}$, the concentration of THMs is approximately double the concentration when $\mathrm{TOC}=3 \mathrm{mg} / \mathrm{L}$. To stay within the allowable level of THM for ROCEPA drinking water quality standard $(100 \mu \mathrm{g} / \mathrm{L})$, the TOC concentration prior to the application of disinfectant should be kept under $4 \mathrm{mg} / \mathrm{L}$.

Table 2. Effect of TOC on THMs formation for applied chlorine dose at $2.0 \mathrm{mg} / \mathrm{L}$ level

\begin{tabular}{cccccc}
\hline \multirow{2}{*}{$\begin{array}{c}\text { Contact time } \\
(\mathrm{min})\end{array}$} & $1 \mathrm{mg} / \mathrm{L}$ TOC & $2 \mathrm{mg} / \mathrm{L}$ TOC & $3 \mathrm{mg} / \mathrm{L}$ TOC & $4 \mathrm{mg} / \mathrm{L}$ TOC & $5 \mathrm{mg} / \mathrm{L} \mathrm{TOC}$ \\
\cline { 2 - 6 } & ND & 3 & 8 & 20 & 39 \\
20 & ND & 5 & 18 & 40 & 75 \\
30 & 0.1 & 7 & 25 & 57 & $* 108$ \\
40 & 0.2 & 9 & 40 & 74 & $* 138$ \\
50 & 0.6 & 10 & 39 & 90 & $* 175$ \\
60 & 0.8 & 12 & 46 & $* 107$ & $* 192$ \\
70 & 2 & 15 & 52 & $* 120$ & $* 238$ \\
\hline
\end{tabular}

* THM concentrations are higher than the drinking water quality standard, i.e. $100 \mu \mathrm{g} / \mathrm{L}$. 
In order to balance the THM formation and disinfection efficiency, a $99.99 \%$ inactivation of the total coliform count in response to the current source water quality in Taiwan, should be provided and shown in Table 3 [14]. With this suggested operation, the plant can be performed to achieve a more stringent standard of THMs, i.e., $60 \mu \mathrm{g} / \mathrm{L}$ in the future [15]. The above evidences provide the referenced background information to set the regulated value of total coliform for ROC source water quality as presented in Table 4. Similar methodologies can be utilized to generate the source water criteria for COD was shown in Table 4 [16].

Table 3. Disinfection efficiency and THM formation during chlorination at $\mathrm{TOC}=3 \mathrm{mg} / \mathrm{L}$

\begin{tabular}{cccc}
\hline \multirow{2}{*}{$\begin{array}{c}\text { Contact time } \\
(\mathrm{min})\end{array}$} & $\mathrm{3} / \mathrm{W}$ ratio $=2$ & L/W ratio $=10$ & L/W ratio $=20$ \\
\cline { 2 - 4 } & $* 99.98$ & 99.98 & 99.99 \\
& $* *(8.85)$ & $(9.97)$ & $(9.99)$ \\
& 99.99 & 99.99 & 99.99 \\
30 & $(13.06)$ & $(14.74)$ & $(14.79)$ \\
& 99.99 & 99.99 & 99.99 \\
40 & $(17.13)$ & $(19.37)$ & $(19.45)$ \\
& 99.99 & 99.99 & 99.99 \\
50 & $(21.06)$ & $(23.88)$ & $(23.99)$ \\
\hline
\end{tabular}

Note: The average level of coliform measured in source water in Taiwan is about 20,000 MPN/100 mL.

* Disinfection efficiency in \% kill.

** The numerical value in the parenthesis denotes the THM formation in $\mu \mathrm{g} / \mathrm{L}$.

Table 4. Proposed source water quality standards in Taiwan, ROC

\begin{tabular}{|c|c|c|c|c|}
\hline \multirow{2}{*}{ Element* } & \multirow{2}{*}{$\begin{array}{l}\text { Current } \\
\text { proposed } \\
\text { standard }\end{array}$} & \multicolumn{2}{|c|}{$\begin{array}{l}\text { Future standard } \\
\text { (Two classifications) }\end{array}$} & \multirow{2}{*}{ Remarks } \\
\hline & & Class 1 & Class 2 & \\
\hline $\begin{array}{l}\text { Total coliform (MPN or } \\
\text { CFU } / 100 \mathrm{~mL})\end{array}$ & 20,000 & 50 & 10,000 & $\begin{array}{l}\text { The principle in determining } \\
\text { future standard is based on: }\end{array}$ \\
\hline Ammonia nitrogen & 1 & 0.5 & 1 & \multirow{5}{*}{$\begin{array}{l}\text { - Class } 1 \text { standard is for } \\
\text { simple water purification } \\
\text { process including } \\
\text { filtration and disinfection } \\
\text { (for surface and } \\
\text { groundwater). }\end{array}$} \\
\hline COD & 25 & 20 & 25 & \\
\hline TOC** & 4 & 2 & 4 & \\
\hline As & 0.05 & 0.05 & 0.05 & \\
\hline $\mathrm{Pb}$ & 0.05 & 0.05 & 0.05 & \\
\hline $\mathrm{Cd}$ & 0.01 & 0.005 & 0.01 & \multirow{4}{*}{$\begin{array}{l}\text { - Class } 2 \text { is the same as } \\
\text { current proposed standard, } \\
\text { it is for conventional water } \\
\text { treatment processes. }\end{array}$} \\
\hline $\mathrm{Hg}$ & 0.002 & 0.001 & 0.002 & \\
\hline $\mathrm{Cr}$ & 0.05 & 0.05 & 0.05 & \\
\hline $\mathrm{Se}$ & 0.05 & 0.01 & 0.05 & \\
\hline
\end{tabular}

* All units are in $\mathrm{mg} / \mathrm{L}$, unless specified otherwise.

** The TOC limit is proposed according to the recommended value from ICR of USEPA. 


\section{Ammonia Nitrogen}

Ammonia nitrogen can be considered as a good indicator both for human pollution in drinking water source and fecal contamination in the water distribution system. Although ammonia nitrogen may not have significant health effects on humans, it causes bad taste and odor in drinking water. In general, conventional coagulation and sedimentation processes are not successfully in removing ammonia nitrogen from the source water. However, most of the water treatment plants in Taiwan have a chlorination process, where the ammonia nitrogen may convert into amine, ammonia, nitrogen oxides or chloramine. Since the purpose of setting ammonia nitrogen standard is for controlling eutrophication in the streams and reservoirs, the adopted standard for the source water shall not be more stringent than the drinking water quality standards $(0.5 \mathrm{mg} / \mathrm{L})$ shown in Table 5. Figure 2 shows the frequency distribution curve of $\mathrm{NH}_{3}-\mathrm{N}$ analyses on the basis of annual average value in the source water measured in Taiwan. It was found that $8 \%$ of the major source water can not meet the criteria, i.e., $1 \mathrm{mg} / \mathrm{L}$ suggested by the council of the European Communities [1]. In response to the high expectation of the drinking water quality by consumers, it is recommended that the ammonia nitrogen limit be set to $1 \mathrm{mg} / \mathrm{L}$ during the first phase from the date of May 30, 1998. The second phase involves enforcing the new standard of $0.5 \mathrm{mg} / \mathrm{L}$ on and after July $1,2000$.

Table 5 Background information pertaining to determination of source water quality standard for ammonia nitrogen

\begin{tabular}{|c|c|c|c|c|}
\hline Item & $\begin{array}{c}\text { Reference } \\
\text { standard } \\
(\mathrm{mg} / \mathrm{L})\end{array}$ & $\begin{array}{l}\text { Source of the } \\
\text { standard }\end{array}$ & $\begin{array}{c}\text { Water quality statistics is } \\
\text { based on the annual } \\
\text { average value in Taiwan, } \\
\text { ROC }\end{array}$ & Discussions and recommendations \\
\hline \multirow[t]{3}{*}{$\begin{array}{l}\text { Ammonia } \\
\text { nitrogen } \\
(\mathrm{mg} / \mathrm{L})\end{array}$} & 0.3 & $\begin{array}{l}\text { Categories B and } \\
\mathrm{C} \text { of ROC } \\
\text { national water } \\
\text { classification }\end{array}$ & $\begin{array}{l}\text { Approximately } 25 \% \text { of } \\
\text { major raw water } \\
\text { sources in Taiwan } \\
\text { cannot meet this value } \\
\text { (based on the annual } \\
\text { average value). }\end{array}$ & \multirow{3}{*}{$\begin{array}{l}\text { Conventional coagulation and } \\
\text { sedimentation processes are ineffective } \\
\text { in removal ammonia nitrogen } \\
\text { - The purpose of setting ammonia } \\
\text { nitrogen criteria is for controlling } \\
\text { eutrophication in the streams and } \\
\text { reservoirs, the adopted criteria shall } \\
\text { not be more stringent than the drinking } \\
\text { water standards ( } 0.5 \mathrm{mg} / \mathrm{L} \text { ). } \\
\text { If } 0.5 \mathrm{mg} / \mathrm{L} \text { is adopted as national } \\
\text { criteria, there are high percentage of } \\
\text { raw water sources will not meet this } \\
\text { criteria. Therefore, } 1 \mathrm{mg} / \mathrm{L} \text { is } \\
\text { recommended at the present time. }\end{array}$} \\
\hline & 0.5 & $\begin{array}{l}\text { Raw water } \\
\text { criteria from } \\
\text { USA } \\
\text { - Class III of } \\
\text { Japanese raw } \\
\text { water criteria }\end{array}$ & $\begin{array}{l}\text { Based on annual } \\
\text { average, approximately } \\
14 \% \text { of major raw } \\
\text { water sources in } \\
\text { Taiwan cannot meet } \\
\text { this value ( } 7 \text { plants). }\end{array}$ & \\
\hline & 1.0 & $\begin{array}{l}\text { Class } A 2 \text { of } E C \\
\text { raw water } \\
\text { criteria }\end{array}$ & $\begin{array}{l}\text { Based on annual } \\
\text { average, approximately } \\
8 \% \text { of major raw water } \\
\text { sources in Taiwan } \\
\text { cannot meet this criteris } \\
\text { ( } 4 \text { plants). }\end{array}$ & \\
\hline
\end{tabular}




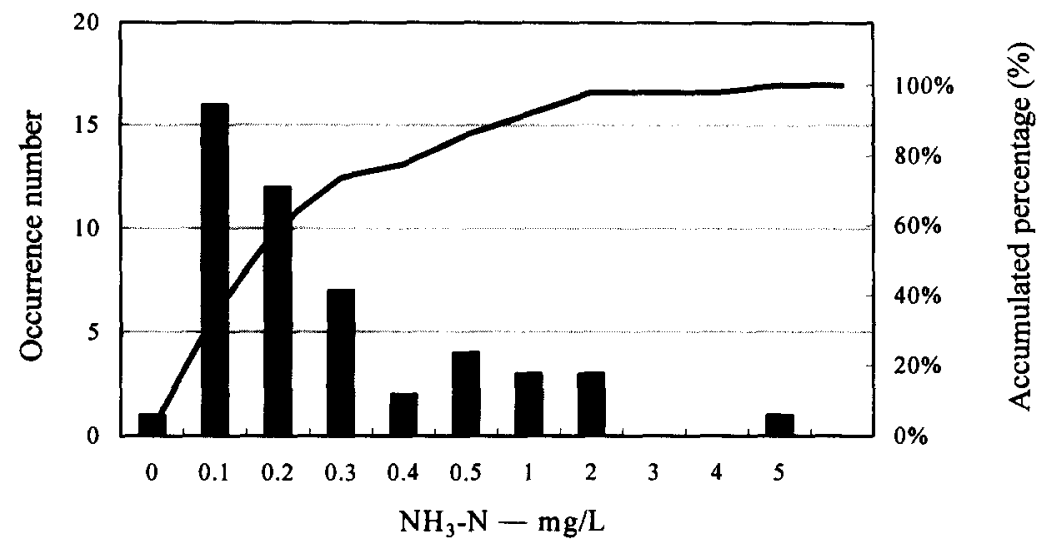

Figure 2. Frequency distribution curve of $\mathrm{NH}_{3}-\mathrm{N}$ analysis in source water measured at the major water treatment plants in Taiwan

\section{Heavy Metals (Arsenic, Cadmium, Chromium. Lead and Mercury)}

As stated previously in Figure 1, the rationale of developing heavy metals standards for the source water quality will include potential health effects, base-line information on domestic source water criteria (or standards) in the developed nations and performance evaluation of treatment plant. Table 6 shows the USEPA National Primary Drinking Water Contaminants Standards for $\mathrm{As}, \mathrm{Cd}, \mathrm{Cr}, \mathrm{Hg}, \mathrm{Pb}$ and $\mathrm{Se}$ which indicated their respective national standards, potential health effects and sources of drinking water contamination. Recently, drinking water quality standards in Taiwan were revised through a procedure of evaluation by experts and scholars in the technical advisory committee. The concept of human health risk assessment would be introduced to amend drinking water quality standards for heavy methods shown in Table 6.

Figure 3 present the frequency distribution curves of $\mathrm{As}, \mathrm{Cd}, \mathrm{Cr}, \mathrm{Hg}$ and $\mathrm{Pb}$ on the basis of annual average value in the source water at the major water treatment plants in Taiwan. All the measurements of $\mathrm{As}$ and $\mathrm{Pb}$ can meet the source water quality standard, i.e., $0.05 \mathrm{mg} / \mathrm{L}$ suggested by class $\mathrm{A} 1$ to $\mathrm{A} 3$ of $\mathrm{EC}$ and Australia Water Criteria (Table 7). Approximately $50 \%$ and $4 \%$ of the major source water have the Cd (or $\mathrm{Cr}$ ) and $\mathrm{Hg}$ contaminants, respectively, but all of them can meet these standards which recommended by the class A1 to A3 of EC and Source Water Criteria from USA. The above heavy metals $(\mathrm{Hg}, \mathrm{Se}) \mathrm{can}$ not be completely treated by the conventional treatment methods (Table 8 ), i.e., coagulation and lime-softening processes. However, they can be further reduced by the ion-exchange and RO membrane methods at the expense of cost. As a result, it would be recommended that toxic chemicals such as heavy metals (As, Cd, $\mathrm{Cr}, \mathrm{Hg}$ and $\mathrm{Pb}$ ) in the source water should be enforced as the contaminant level suggested by the drinking eater quality standard. 

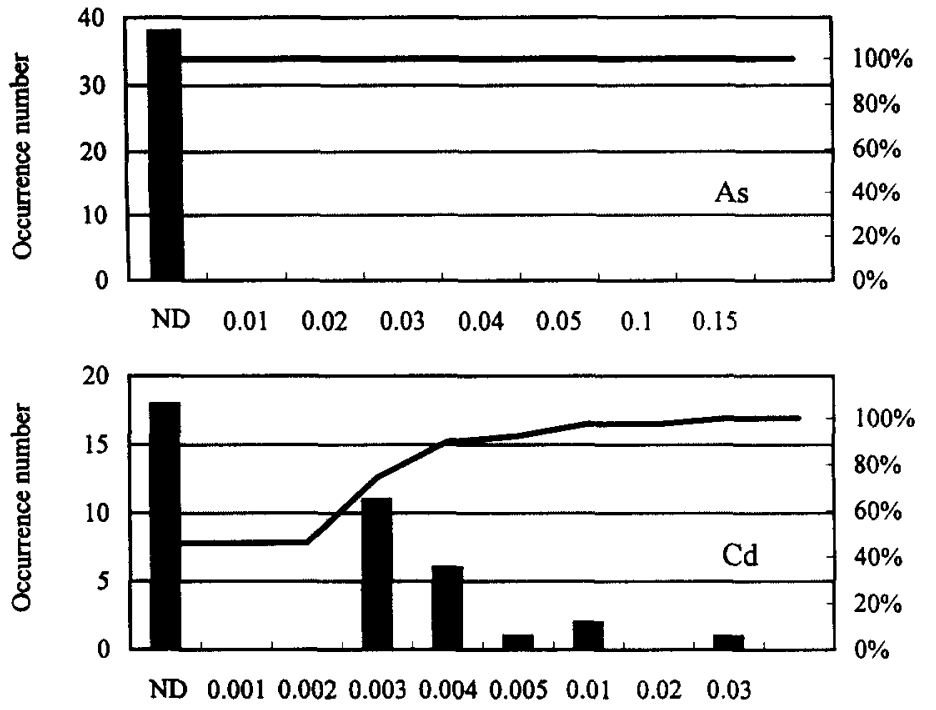

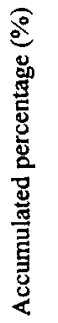

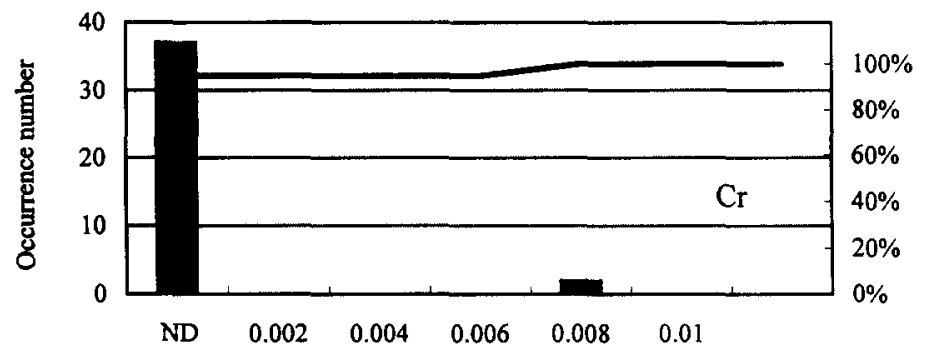

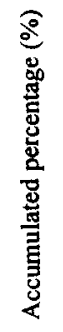
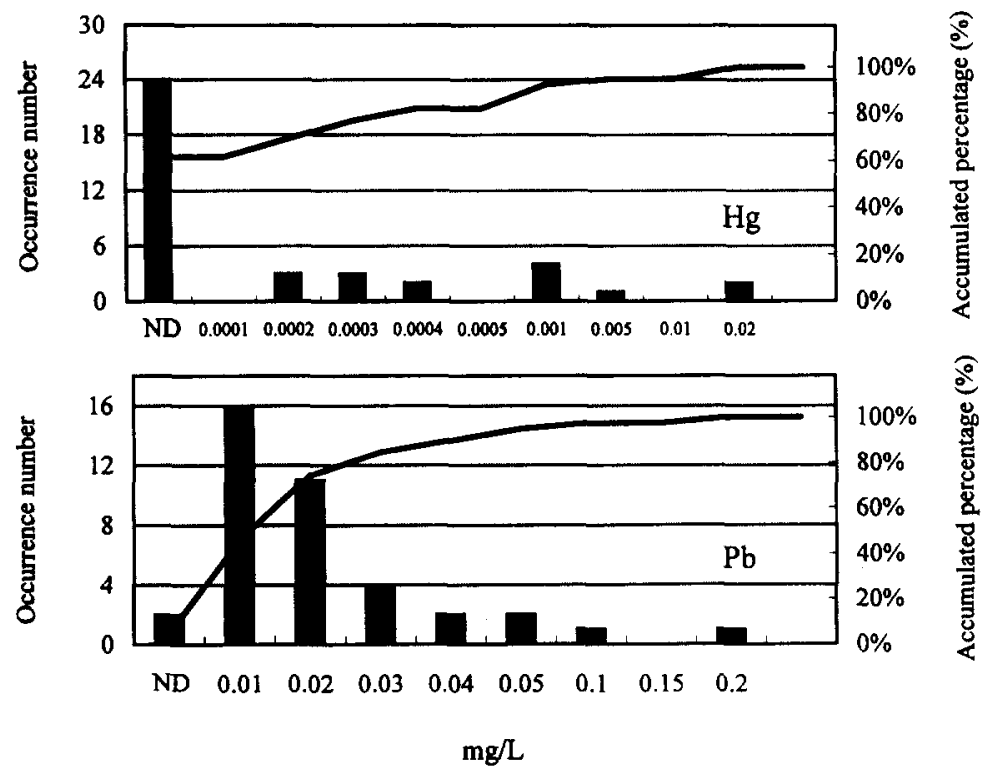

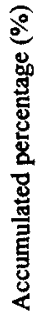

Figure 3. Frequency distribution curves of $\mathrm{As}, \mathrm{Cd}, \mathrm{Cr}, \mathrm{Pb}$, and $\mathrm{Hg}$ analyses on the basis of annual average value in source water measured at the major water treatments in Taiwan 
Table 6. National primary drinking water contaminants standards $[17,18]$

\begin{tabular}{|c|c|c|c|c|c|c|c|}
\hline Contaminant & WHO & U.K. & USA & $\mathrm{EC}$ & Japan & $\begin{array}{l}\text { Potential Health } \\
\text { Effects }\end{array}$ & $\begin{array}{c}\text { Sources of Drinking Water } \\
\text { Contamination }\end{array}$ \\
\hline Arsenic & 0.01 & 0.05 & 0.05 & 0.05 & 0.01 & $\begin{array}{l}\text { Skin, nervous } \\
\text { system toxicity, } \\
\text { cancer }\end{array}$ & $\begin{array}{l}\text { Natural deposits; smelters, glass, } \\
\text { electronics wastes; orchards }\end{array}$ \\
\hline Cadmium & 0.003 & 0.005 & 0.005 & 0.005 & 0.01 & Kidney effects & $\begin{array}{l}\text { Galvanized pipe corrosion; Natural } \\
\text { deposits; batteries, paints }\end{array}$ \\
\hline $\begin{array}{l}\text { Chromium } \\
\text { (total) }\end{array}$ & 0.05 & 0.05 & 0.1 & 0.05 & 0.05 & $\begin{array}{l}\text { Liver, Kidney, } \\
\text { circulatory } \\
\text { disorders }\end{array}$ & $\begin{array}{l}\text { Natural deposits; mining, } \\
\text { electroplating, pigments }\end{array}$ \\
\hline $\begin{array}{l}\text { Mercury } \\
\text { (inorganic) }\end{array}$ & 0.001 & 0.001 & 0.002 & 0.001 & 0.0005 & $\begin{array}{l}\text { Kidney, nervous } \\
\text { system disorders }\end{array}$ & $\begin{array}{l}\text { Crop runoff; natural deposits; } \\
\text { batteries electrical switches }\end{array}$ \\
\hline Lead & 0.01 & 0.05 & $\mathrm{TT}^{*}$ & 0.05 & 0.05 & $\begin{array}{l}\text { Kidney, nervous } \\
\text { system damage }\end{array}$ & $\begin{array}{l}\text { Natural/industrial deposits; plumbing } \\
\text { solder, brass allow faucets }\end{array}$ \\
\hline Selenium & 0.01 & 0.01 & 0.05 & 0.01 & 0.01 & Liver damage & $\begin{array}{l}\text { Natural deposits; mining, Smelting, } \\
\text { coal/oil combustion }\end{array}$ \\
\hline
\end{tabular}

\#Treatment Technique Requirement

Table 7. Background information pertaining to determination of Source Water Quality Standard for heavy metals

\begin{tabular}{|c|c|c|c|c|}
\hline Item & $\begin{array}{c}\text { Referenced } \\
\text { standard } \\
\text { (mg/L) }\end{array}$ & Source of the Standard & $\begin{array}{c}\text { Water Quality statistics based } \\
\text { on the annual average value in } \\
\text { Taiwan, ROC }\end{array}$ & $\begin{array}{l}\text { Discussions and } \\
\text { Recommendations }\end{array}$ \\
\hline As & 0.05 & $\begin{array}{l}\text { - Class } 1 \text { to } 3 \text { of ROC National Water } \\
\text { Classification } \\
\text { - Class A1 to A3 of EC Source Water } \\
\text { Criteria } \\
\text { - Australia Water Criteria }\end{array}$ & $\begin{array}{l}\text { Not observed in the major } \\
\text { source water, with the } \\
\text { exception of some ground } \\
\text { water. }\end{array}$ & \multirow{6}{*}{$\begin{array}{l}\text { - Heavy metals can } \\
\text { not be completely } \\
\text { removed by the } \\
\text { conventional } \\
\text { treatment process } \\
\text { with the pH } \\
\text { adjustment ( } 6 \text { to } \\
8 \text { ). } \\
\text { - As (or other } \\
\text { metals) can be } \\
\text { furthered treated } \\
\text { by the Ion- } \\
\text { exchange and RO } \\
\text { membrane } \\
\text { processes at the } \\
\text { expense of cost. } \\
\text { - Toxic chemical } \\
\text { should be } \\
\text { enforred as the } \\
\text { contaminant level } \\
\text { suggested by the } \\
\text { drinking water } \\
\text { quality standard } \\
\text { (0.05 mg/L). }\end{array}$} \\
\hline Cd & 0.01 & $\begin{array}{l}\text { - Class } 1 \text { to } 3 \text { of ROC National Water } \\
\text { Classification } \\
\text { - Source Water Criteria from USA } \\
\text { - Class I to III of Japanese Source } \\
\text { Water Criteria } \\
\end{array}$ & $\begin{array}{l}\text { - Approximately } 50 \% \text { of } \\
\text { major source water in } \\
\text { Taiwan can measure the Cd } \\
\text { contaminant but all of them } \\
\text { can meet this standard. }\end{array}$ & \\
\hline $\mathrm{Cr}$ & 0.05 & $\begin{array}{l}\text { - Class } 1 \text { to } 3 \text { of ROC National Water } \\
\text { Classification } \\
\text { - Class A1 to A3 of EC Source Water } \\
\text { Criteria } \\
\text { - Class I to III of Japanese Source } \\
\text { Water Criteria } \\
\text { - Australia Water Criteria } \\
\text { - Source Water Criteria from USA }\end{array}$ & $\begin{array}{l}\text { - Approximately } 50 \% \text { of } \\
\text { major source water in } \\
\text { Taiwan can measure the } \mathrm{Cr} \\
\text { contaminant but all of them } \\
\text { can meet this standard. }\end{array}$ & \\
\hline $\mathrm{Hg}$ & 0.002 & $\begin{array}{l}\text { - Class } 1 \text { to } 3 \text { of ROC National Water } \\
\text { Classification } \\
\text { - Source Water Criteria from USA }\end{array}$ & $\begin{array}{l}\text { - Approximately } 40 \% \text { of } \\
\text { major source water in } \\
\text { Taiwan can measure the } \mathrm{Hg} \\
\text { contaminant but all of them } \\
\text { can meet this standard. } \\
\end{array}$ & \\
\hline $\mathrm{Pb}$ & 0.05 & $\begin{array}{l}\text { - Class } 1 \text { to } 3 \text { of ROC National Water } \\
\text { Classification } \\
\text { - Class A1 to A3 of EC Source Water } \\
\text { Criteria } \\
\text { - Australia Water Criteria } \\
\text { - Source Water Criteria from USA } \\
\end{array}$ & $\begin{array}{l}\text { - } 39 \text { major source water in } \\
\text { Taiwan can meet this } \\
\text { standard. }\end{array}$ & \\
\hline $\mathrm{Se}$ & 0.05 & $\begin{array}{l}\text { - Class } 1 \text { to } 3 \text { of ROC National Water } \\
\text { Classification }\end{array}$ & - Not available & \\
\hline
\end{tabular}


Table 8. The optimum pH value and removal efficiency for heavy metals reduction by coagulation and lime-softening processes

\begin{tabular}{|c|c|c|c|c|c|}
\hline \multirow{3}{*}{ Inogranics } & \multicolumn{3}{|c|}{ Coagulation } & \multicolumn{2}{|c|}{ Lime-softening } \\
\hline & \multirow{2}{*}{$\mathrm{pH}$} & \multicolumn{2}{|c|}{ Removal efficiency (\%) } & \multirow{2}{*}{$\mathrm{pH}$} & \multirow{2}{*}{$\begin{array}{c}\text { Removal efficiency } \\
(\%)\end{array}$} \\
\hline & & Alum & Iron & & \\
\hline \multirow[t]{2}{*}{ As } & $6-7$ & 90 & - & $>10.5$ & 70 \\
\hline & $6-8$ & - & 90 & & \\
\hline $\mathrm{Cd}$ & $>8.5$ & 70 & - & - & 90 \\
\hline \multirow[t]{2}{*}{$\mathrm{Cr}$} & $7-9$ & 90 & & $>10.5$ & $70-90$ \\
\hline & $7-10.5$ & & 90 & & \\
\hline $\mathrm{Se}$ (IV) & 6.7 & - & 50 & - & - \\
\hline $\mathrm{Hg}$ & $7-9.5$ & - & 70 & - & - \\
\hline $\mathrm{Pb}$ & $6-9$ & 90 & 90 & - & 90 \\
\hline
\end{tabular}

\section{REGULATIONS FOR SOURCE WATER PROTECTION}

Source water protection serves an absolute and un-disputable purpose, that is, to provide water of the highest quality for human consumption at sufficient quantity. To achieve this goal, it is necessary to take multi-barrier approach, that is to consider all aspects of water quality management including source protection, treatment and distribution system protection. Filtration, disinfection, covering treated water reservoirs, residual disinfectant, in addition to source water protection are the required measures for water quality assurance. As long as source water protection is concerned, it should introduce the important water quality parameters such as microbes (total coliforms), synthetic organic chemicals (COD, TOC), and inorganic chemicals ( $\mathrm{As}, \mathrm{Cd}, \mathrm{Cr}, \mathrm{Hg}, \mathrm{Pb}$ and $\mathrm{Se}$ ) into the source water quality standards.

In August of 1997, USAEPA has issued guidelines on source water protection, which is a major step in drinking water quality management. Immediate task under this new guideline is the establishment of a national source water assessments program (SWAP) in which the delineation of source water protection area and water quality assessment are the priority task forces should be performed. For any source water protection program to be successful, it is necessary to have enforceable implementation plans, strong institutions and organizations, adequate financial and human resources, and third party facilitations.

According to the regulations for ROCEPA source water management [19] promulgated in May 21, 1997 , it is clearly stated that any human activity may pollute the water within a source water quality protection area or an area within a certain distance from a water-intake point would be prohibited. The above "human activity may pollute water" refers to:

1. illegal logging or land development;

2. development of industrial parks or establishment of polluted factories; 
3. development of nuclear and other energy-generating facilities as well as construction of radioactive waste storage or disposal site;

4. dumping, disposing or discarding of garbage, ashes, gravel and soil, sludge, excrement and urine, waste oil, waste chemicals, animal carcasses, or other wastes which may pollute source water quality;

5. commercial poultry and livestock operations;

6. development of new residential communities, excluding the aboriginal communities as a result of population growth;

7. construction or expansion of golf courses;

8. excavation of gravel, soil and ore;

9. development of a railroad, mass transit system, harbor, or airport subject to the environmental impact assessment process based on the scope and scale of the construction construction project;

10. alterations of river course affecting its self-purification ability without obtaining a permit in advance from the responsible agency ;

11. construction of roads and sports fields without obtaining a permit in advance from the responsible agency other activities designated the sufficient and announced by the central government.

\section{IMPLEMENTATION PLANS FOR NATIONAL SOURCE WATER QUALITY}

Successful legislations require the sufficient scientific data and strong technology support. For instance, good understanding of the hydrologic properties of watershed including flow velocity, traveling time, order of streams and tributaries, geology and vegetation and discharge points for developing the river basin modeling is also essential to source water protection. Finally, the occurrence of natural organic matter (NOM) affecting the formation of DBPs can not be ignored.

Source water protection can not be the sole responsibility of the water industry. Sufficient fund must be available and that institutional support is also essential. The following are some suggestions for the source water protection measures in Taiwan:

1. Designation of source water quality protection zone

The following areas have been designated as source water quality protection zones:
a. Watersheds promulgated as source water for water treatment plants.
b. Watersheds used or planned for source water.
c. Areas assigned by local governments.

\section{Determination of suitable distance from water intakes}

a. Use GIS (Geographic information system) process to delineate watershed for 21 major streams and 29 secondary streams. 
b. Locate existing water intakes and potential water intakes in the watershed map.

c. Designate $0.5 \mathrm{~km}$ downstream and one $\mathrm{km}$ upstream from each water intake as primary protection area (A). A 100-meter buffer zone will be imposed within Area A along waterways. Absolute no human activities within buffer zone. Designate $2 \mathrm{~km}$ upstream from Area A as secondary protection area (B). A 50-meters buffer zone will be imposed within Area B along waterways. Absolute no human activities within buffer zone.

\section{Execution of Water Pollution Control Projects}

It is important to coordinate government organizations from different ministries and levels (central, provincial, and local) for a successful water pollution control project. The following are some projects proposed for control of the water pollution and protection of the source water:

a. Establishment of the "source water quality protection zone" to reduce the levels of water pollutants;

b. Construction of sewerage systems and interception stations for the major source water;

c. Development of watershed management and soil conservation;

d. Technical assistance to set up pollution control facilities for industry;

e. Execution of pollution fee for construction of the sewerage systems and the small wastewater treatment plants in source water protection zones

\section{UPGRADING OF EXISTING WATER TREATMENT FACILITIES BY THE CCP/CPE TECHNIQUES}

The source water quality standard proposed by ROCEPA is intended to push the water industry to upgrade the existing facilities or install the advanced treatment process, if the source water quality cannot comply with the standards. Figure 4 presents the standard operational procedures concerning the EPA review and approval process for a water treatment plant whose source water quality exceeds the national limit listed in Table 1. Both the CCP (Composite Correction Program) and CPE (Comprehensive Performance Evaluation) techniques suggested by USEPA [7] were introduced to determine if searching for an alternate source water or optimizing (or upgrading) the existing water treatment is required throughout the EPA review and process shown in Figure 4.

The CPE method is a systematic approach to assess the unit treatment process capabilities for an existing plant. Technical informations including raw and treated water quality, design and operating conditions for individual plant processes, plant operator coverage, user fees for water treatment, maintenance scheduling, and operating budgets from the target plant should be gathered to make critical review by the CPE team. The corrective actions should be performed to achieve the desired water quality through use of the CCP. 


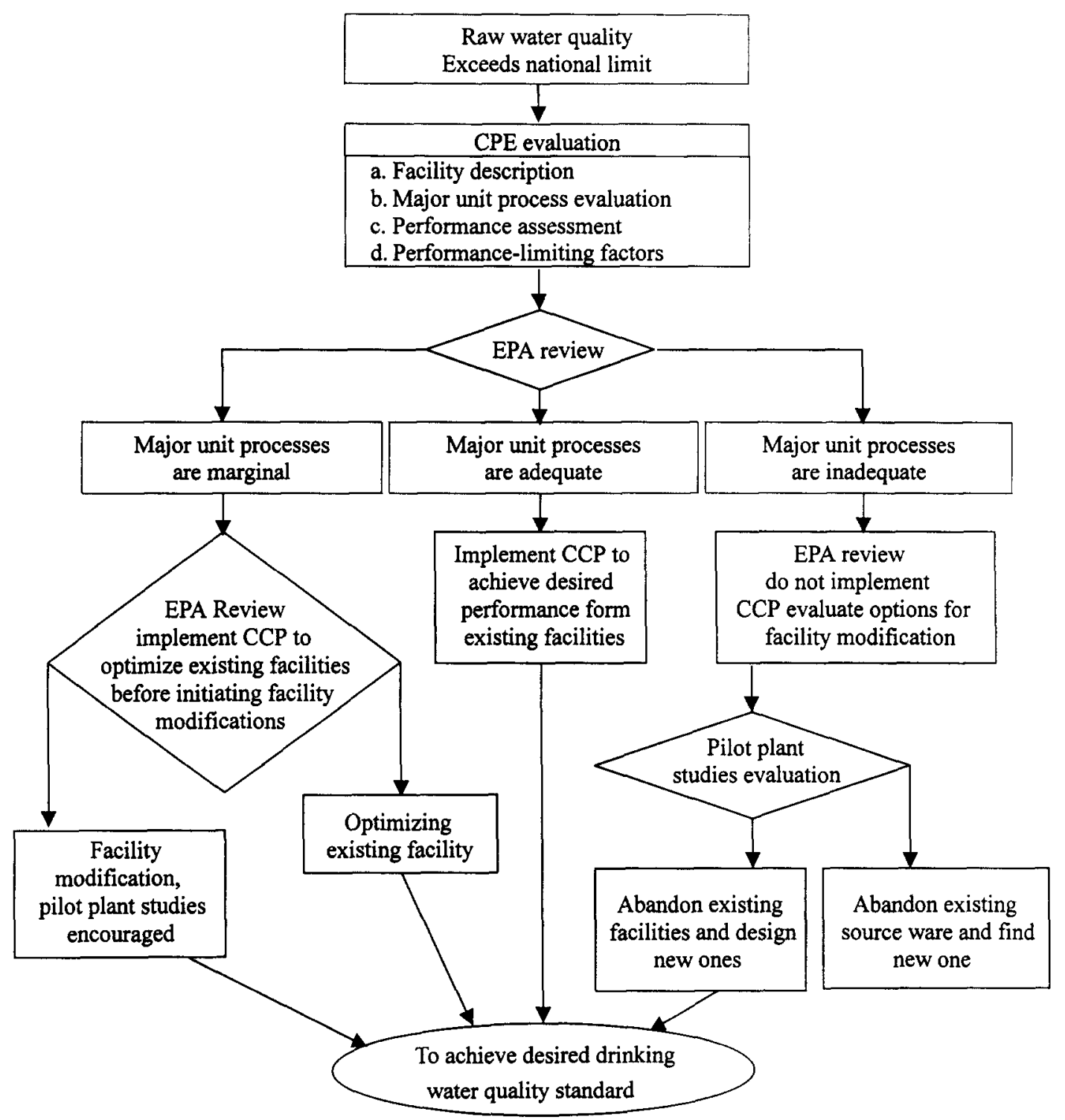

Figure 4. Standard operational procedures for reviewing and/or approving a water treatment plant whose source water quality exceeding the national limit

\section{CONCLUSIONS AND RECOMMENDATIONS}

Due to the unique geographical and socio-economical situations in Taiwan, its source waters are prone to various contaminants. The Environmental Protection Administration of ROC is seeking cost-effective alternatives to meet the drinking water standards. This research work is intended to develop more stringent 
regulations to protect drinking water sources and to comply with requirements of drinking water standards. The water quality parameters for source water standards should be a representative indicator for water pollution referred to toxic or hazardous contaminants which have been adopted by the developed nations. The regulated values for the above parameters should consider the existing and future drinking water standards, background data of the current source water quality, the introduced water treatment processes and administrative and analytical problems encountered during execution of the source water standard. As suggested by USEPA Disinfectant/Disinfection by-product rules and our previous research work, it might adopt $4.0 \mathrm{mg} / \mathrm{L}$ TOC as a source water criteria at the present time and to implement more stringent value (2.0 $\mathrm{mg} / \mathrm{L}$ TOC) in the next phase. Since the purpose of setting ammonia nitrogen standard is for controlling eutrophication in the streams and reservoirs, the adopted standard for the source water should follow the limit, i.e., $1 \mathrm{mg} / \mathrm{L}$ suggested by the council of the European Communities. Toxic chemicals such as heavy metals ( $\mathrm{As}, \mathrm{Cd}, \mathrm{Cr}, \mathrm{Pb}$ and $\mathrm{Hg}$ ) in the source water should be enforced as the contaminant level suggested by the drinking water quality standard.

Recently, the Statute Governing Drinking Water (Amendment) has been passed by the Legislative Yuean, ROC. EPA then can be authorized to issue the Source Water Quality Standard. With this successful recognition by the public, the source water quality standards will presumptively provide implementation plans to reach the goal of safe drinking water Taiwan. The ROCEPA will promulgate the source water quality protection zones and set up a proper distance from the source water intake to minimize source pollutions for protection of the source water. The EPA will also coordinate a task force, consisting of members from different levels of government agencies, to supervise the water pollution control programs in the source water protection zones. The other measure is to use groundwater recharge pretreatment method to reduce the level of contaminants. Furthermore, in order to meet national drinking water standards it is important that new advanced treatment technologies be introduced to the water treatment plants throughout the of CPE and CCP procedures. In addition, there is a great need for the continuing training of local government personnel so as to improve skills in water quality monitoring and analysis. The National Environmental Laboratory can provide guidance and laboratory certification. It is thus concluded that development of the source water protection zone, execution of water pollution control projects and improvement of water treatment technologies are the essential tasks should be implemented by the central and local governments.

\section{REFERENCES}

1. Council of the European Communities, Concerning the Quality Required of Surface Water Intended for the Abstraction of Drinking Water in the Member States. Official Journal of the European Communities, June 16, Luxembourg, pp. 26-31 (1975).

2. Institute of Public Health, Water Quality Standards, Tokyo, Japan (1970). 
3. National Academy of Sciences - National Academy of Engineering, Water Quality Criteria. A report of the Committee on Water Quality Criteria, at the request of and funded by the Environmental Protection Agency, Washington, D.C. (1972).

4. ROCEPA, Water Pollution Control Act, May 6 (1991).

5. J.H. Yeh, M.H. Hsu, E.E. Chang and C.P. Huang, Development of statute governing drinking water and strategic plan for drinking water research in ROC. Proceeding $3^{\text {nt }}$ International Workshop on Drinking Water Quality Management and Treatment Technology, March 5-6, Taiwan, ROC, pp. 103-117 (1997).

6. E.E. Chang, Rational study on establishing National Source Water Quality Standards, ROC EPA-86- J02-09-07 (1997).

7. F.W. Pontius, An update of the federal drinking water regs., J. $A W W A, 87$ (2), pp. 48-58 (1995).

8. E.E. Chang, P.C. Chiang and Y.C. Chou, Drinking Water Quality Standards: Establishment and implementation, Proceedings of $2^{\text {nd }}$ International Workshop on Drinking Wafer quality Management and Treatment Technology, May 9-10, pp.245-251, Taiwan, ROC (1996).

9. R.A. Dobbs, R.H. Wise and R.B. Dean, The use of ultraviolet absorbance for monotoring the total organic carbon of water and wastewater, Water Res., 6, pp. 1173-1180 (1972).

10. A.L. Wilson, Determination of fulvic acids in water, J. Appl. Chem., 9, pp. 501 (1959).

11. A. L. Copper, and J.C. Young, Chemical Non-specific organic analysis, In R.A. Minear and L. Keith, eds., Water Analysis, Vol.3, Academic Press, New York (1984).

12. USEPA, Enhanced Surface Water Treatment Rule, July 29 (1994).

13. USEPA, Disinfectants/Disinfection By-Products Rule, July 29 (1994).

14.P.C. Chiang, E.E. Chang, Y.W. Ko and J.C. Lou, Balancing disinfection efficiency and THM formation during chlorination: Theoretical considerations, Can. J. Chem. Eng., 75, pp. 892-898 (1997).

15. USEPA, Information Collection Rule, Feb. 10 (1994).

16. E.E. Chang, P.C. Chiang and T.F. Lin, Development of surrogate organic contaminants parameters for source water quality standards in Taiwan, ROC, Chemosphere, 37 (4), pp. 593-606 (1998).

17.F.W. Pontius, SDWA Advisor on CD-ROM Regulatory Update Service, American Water Works Association, Denver, Colo. (1998).

18. E.E. Chang, P.C. Chiang and J.H. Yeh, Rationale to establish drinking water quality standards, in Taiwan, ROC, $11^{\text {th }}$ IWSA-ASPAC Regional Conference and Exhibition, November 1-5 ,pp. 33-40, Sydney Australia (1998).

19. ROCEPA, Drinking Water Management Act, May 21 (1997). 